\title{
Accumulation and biological cycling of heavy metal elements in Rhizophora stylosa mangroves in Yingluo Bay, China
}

\author{
Zheng Wen-jiao ${ }^{1}$, Chen Xiao-yong ${ }^{2}$, Lin Peng ${ }^{2}$ \\ ${ }^{1}$ Environmental Science Research Center, ${ }^{2}$ Department of Biology, Xiamen University, Xiamen 361005, \\ People's Republic of China
}

\begin{abstract}
Absorption, accumulation and dynamics of 7 heavy metal elements were studied in mature Rhizophora stylosa mangroves in Yingluo Bay, China. The concentrations of $\mathrm{Cu}, \mathrm{Pb}, \mathrm{Zn}, \mathrm{Cd}, \mathrm{Cr}$, $\mathrm{Ni}$ and $\mathrm{Mn}$ in the sediments of the mangrove forest were determined to be 18.9, 10.0, 46.6, 0.077, 9.27, 14.6 and $89.5 \mathrm{\mu g} \mathrm{g}^{-1}$ dry wt, respectively. Evident differences of heavy metal concentrations have been observed in different parts of the plant, and the weighted means were $0.98,0.86,4.91,0.11,0.50,1.06$ and $14.60 \mu \mathrm{g} \mathrm{g}^{-1} \mathrm{dry}$ wt for $\mathrm{Cu}, \mathrm{Pb}, \mathrm{Zn}, \mathrm{Cd}, \mathrm{Cr}, \mathrm{Ni}$ and $\mathrm{Mn}$ respectively. In natural habitat conditions, the ability of $R$. stylosa to absorb each heavy metal except $C d$ was very low, and the weighted average accumulation indices of $\mathrm{Cu}, \mathrm{Pb}, \mathrm{Zn}, \mathrm{Cd}, \mathrm{Cr}, \mathrm{Ni}$ and $\mathrm{Mn}$ in the plant to those in soil were only $0.05,0.09$, $0.11,1.40,0.05,0.07$ and 0.16 , respectively. The heavy metal concentrations in residues on the floor were much higher than those in the plant and in litter falls. The total amounts of $\mathrm{Cu}, \mathrm{Pb}, \mathrm{Zn}, \mathrm{Cd}, \mathrm{Cr}, \mathrm{Ni}$ and $\mathrm{Mn}$ in the standing crop of the forest were $28.73,25.25,143.68,3.14,14.61,30.87$ and $430.39 \mathrm{mg}$ $\mathrm{m}^{-2}$, among which about 90 to $96 \%$ of the total amounts was stored in the parts difficult to consume by the animals. The storages in residues on the floor were $271.7,323.5,1983.8,8.2,34.4,63.0$ and $1776.9 \mathrm{~g} \mathrm{~m} \mathrm{~m}^{-2}$, respectively. With the development of leaves from young to old, $\mathrm{Cu}, \mathrm{Zn}$ and Ni can be translocated and reused before defoliation, while amounts of other heavy metal elements increased in older leaves. In the biological cycle of 7 heavy metals in the forest the following was observed: (1) the annual uptakes of $\mathrm{Cu}, \mathrm{Pb}, \mathrm{Zn}, \mathrm{Cd}, \mathrm{Cr}, \mathrm{Ni}$ and $\mathrm{Mn}$ by the forest were 1351.7, 1613.1, 8808.4, 240.7, 759.5, 1627.7 and $53692.0 \mu \mathrm{g} \mathrm{m}^{-2}$; (2) annual retentions were $842.5,806.9,4694.2,95.0,464.9,1054.0$ and $14038.9 \mathrm{\mu g} \mathrm{m}^{-2}$, respectively; (3) annual returns were $509.2,806.2,4114.3,146.0,294.6,573.7$ and $3965.3 \mu \mathrm{g} \mathrm{m}^{-2}$, respectively. The estimated turnover periods were $56,31,35,22,50,54$ and $11 \mathrm{yr}$ for $\mathrm{Cu}$, $\mathrm{Pb}, \mathrm{Zn}, \mathrm{Cd}, \mathrm{Cr}, \mathrm{Ni}$ and $\mathrm{Mn}$, respectively.
\end{abstract}

KEY WORDS: Mangroves - Heavy metal - Biological cycling $\cdot$ Rhizophora stylosa

\section{INTRODUCTION}

Mangroves are intertidal wetlands, common in tropical and subtropical coastal environments, especially in bays and estuaries. They support genetically diverse communities of terrestrial and aquatic organisms of direct and indirect socio-economic value. As the primary producer, mangroves supply food for marine animals. They also provide habitats for birds, insects, fishes, algae and bacteria. They consist of complex food chains or food webs (Teas 1979, Lin 1988). Due to the discharge of pollutants caused by the rapid development of cities along the coast and rivers, the envi- ronmental stresses on estuary mangrove ecosystems have increased.

Heavy metals are one of the most important pollutants and their effects on mangroves have been widely recognized (Walsh et al. 1979, Lin \& Chen 1989, Mackey et al. 1992, Tam et al. 1995). Mangrove sediments are important sinks for land-derived contaminants, especially heavy metals. The urban and industrial activities in coastal areas and along rivers cause a significant increase in metal concentrations in solution and suspension in water, which converge to the estuary mangrove wetlands. The metals are trapped by the sediments, due to the sedimentation of suspended par- 
ticles and various retention processes associated with surfaces of the sediment organic and inorganic matter The fates of nutrients and trace elements in sediments of mangrove swamps have been widely studied. But, few studies on the dynamics of heavy metals in the mangrove community have been reported. However, to quantify the relevance of the heavy metal accumulation process and the consequent segregation from the estuarine environment, a better knowledge of the capacity of the plant species involved in drawing the metals from sediments and releasing them as plant detritus to the estuarine food chains is needed (Lacerda \& Abrao 1984).

The Rhizophora stylosa mangroves in Yingluo Bay, China, are one of the mangroves typical to China. Very little information is available on the characteristics of the mangroves, and most of the studies performed focused on community structure. Until now, no research data have been reported on heavy metals in sediments and plants and their dynamics in this mangrove ecosystem.

This paper deals with the absorption, accumulation and dynamics of 7 heavy metals in a Rhizophora stylosa forest. The aim is to reveal the actions of various heavy metals in $R$. stylosa mangroves.

\section{MATERIALS AND METHODS}

The research site is located in Shankou Mangrove Nature Reserve of Yingluo Bay $\left(21^{\circ} 28^{\prime} \mathrm{N}, 119^{\circ} 43^{\prime} \mathrm{E}\right)$ in China, which is sited at the northeastern edge of Beibu Gulf, the mangroves occupying an area of about 730 ha. The dominant species is Rhizophora stylosa, although a total of 9 mangrove species occur in this forest (Lin \& Hu 1983). This is the best conserved and largest area of $R$. stylosa forest in China. The research site was protected as a national class mangrove nature reserve in 1990 and hardly suffers disturbance. The waterway, with significant freshwater input, is the Lianjiang River, which flows into the northern portion of the bay. The river is clean, because the areas which the river flows through have very few industrial activities.

The studied community is a mature pure Rhizophora stylosa forest of some $87 \mathrm{hm}^{2}$ in mid-tidal zone. It is about $70 \mathrm{yr}$ in age, $6 \mathrm{~m}$ in height, and 74 ind. per $100 \mathrm{~m}^{2}$ in density. Trunk diameters at breast height are 5 to $11 \mathrm{~cm}$. The plants have well-developed stilt roots and are rich in aerial roots. The leaf area index of the forest is 2.9, and the cover is 0.9 . The forest is affected by tides occurring at regular intervals. Salinity of surface soil is $21.21 \%$, pH value 4.61 and organic matter content $13.4 \%$ (Lin et al. 1992).

The research was conducted in 1993. Five sample sites were selected in the forest. One was at the center of the forest, and the other 4 were about $50 \mathrm{~m}$ away from the center site on its 4 aspects. Each sample site was about $100 \mathrm{~m}^{2}$ At each sample sites, fresh leaf, flower, fruit, twig, branch, trunk wood, trunk bark, aerial root, stilt root and underground root of Rhizophora stylosa were sampled randomly, $500 \mathrm{~g}$ of each component was collected. Residues in four $1 \times 1 \mathrm{~m}^{2}$ plots were all collected and 5 surface soil samples $(0$ to $30 \mathrm{~cm}$ in depth) were sampled randomly at each sites. All the samples from the 5 sites were mixed extensively according to the component. The plant samples and residue samples were taken to the laboratory immediately, washed with distilled water and dried at $60^{\circ} \mathrm{C}$. Litter fall was collected continuously for $3 \mathrm{yr}$ using 15 traps of $1 \times 1 \mathrm{~m}^{2}$ hung randomiy among plants about $2 \mathrm{~m}$ above the ground (F. Z. Zheng et al. 1996).

In order to reveal the changes of heavy metal concentrations in a leaf during its development, leaves at 3 different stages of development were sampled from the same branch: young leaf (the first leaf pair), mature leaf (the third leaf pair), and yellow leaf (turning yellow for senescence).

All the samples were dried to constant weight at $60^{\circ} \mathrm{C}$, ground, and then stored for analysis. The samples were digested by $\mathrm{HNO}_{3}-\mathrm{HClO}_{3}$. Concentrations of $\mathrm{Cu}, \mathrm{Pb}, \mathrm{Zn}, \mathrm{Cd}, \mathrm{Cr}, \mathrm{Ni}$ and $\mathrm{Mn}$ were analyzed with atomic absorption spectrophotometers.

The standing crop and annual increment data were from Lin et al. (1992). Data on litter fall were from F. Z. Zheng et al. (1996). The amount of residues on the floor was measured seasonally.

The standing amount of heavy metals stored in the standing crop reflects the net accumulations of elements absorbed by the forest, which is calculated from the concentrations of heavy metals in each component sampled and the biomass of the forest. The potential amount of heavy metals in the residues on the floor is also calculated from the concentration of heavy metals in each fraction of the residues and the amounts of the residues.

The absorption ability of a plant for heavy metals in the soil is generally expressed by an accumulation coefficient. It can be calculated using the formula: $D_{i}=C_{i} / C_{\text {soil }}$, where $D_{1}$ is the accumulation coefficient for heavy metal $i, C_{i}$ is the concentration of the heavy metal in the plant, and $C_{\mathrm{soil}}$ is the concentration of the heavy metal in the soil.

In an ecosystem, biological cycling means the cycling of materials among soil, plants and animals. This paper only deals with the cycling between plants and soil, which includes 3 processes: uptake, retention and return (Qu et al. 1983). Annual retention is the net accumulated amount of a heavy metal element in the forest in $1 \mathrm{yr}$, obtained from the annual increment of biomass of each fraction of the forest and the concen- 
trations of the elements in each fraction (Zheng \& Lin 1992). Annual return is the returned amount of a heavy metal in $1 \mathrm{yr}$, including the return by litter fall, dead root and that leached by rain, etc. Because it is difficult to measure the returns of an element via dead root, root secretion and rain leaching in a mangrove swamp, we only estimated the annual return via litter fall (Zheng \& Lin 1992). So, the estimated values of return are underestimated slightly. The amount of uptake is equal to the total of retentions and returns.

The turnover period of an element in vegetation is the ratio of the total amount of the element in the standing crop to that in the annual litter fall. That is $P_{i}=S_{1} / R_{1}$, where the $P_{i}$ is the turnover period of element $i_{1} S_{i}$ is the standing amount of the element, and the $R_{l}$ is the annual return. The absorption coefficient, utilization coefficient and cycling coefficient can be used as another cycling index of an element between the forest and its habitats, and were calculated according to Chen \& Lindley (1983).

\section{RESULTS}

\section{Heavy metals in components of Rhizophora stylosa mangroves}

Heavy metal concentrations in sediments

The concentrations of $\mathrm{Cu}, \mathrm{Pb}, \mathrm{Zn}, \mathrm{Cd}, \mathrm{Cr}, \mathrm{Ni}$ and $\mathrm{Mn}$ in sediments ( 0 to $30 \mathrm{~cm}$ deep) in the Rhizophora stylosa forest of Yingluo Bay are shown in Table 1. The mean metal concentrations were found to decrease in the order $\mathrm{Mn}>\mathrm{Zn}>\mathrm{Cu}>\mathrm{Ni}>\mathrm{Pb}>\mathrm{Cr}>\mathrm{Cd}$. This pattern is similar to the River Tees estuary, UK, sediments reported by Davies et al. (1991). All of them except $\mathrm{Cr}$ were lower than the concentrations of the corresponding elements in sediments in a Kandelia candel forest of Jiulong River Estuary (W. J. Zheng et al. 1996a, b) and in an Avicennia marina forest of Shenzhen Bay, China (Zheng \& Lin 1996a, b). These values were similar to or lower than those in Sepetiba Bay of Brazil (Lacerda \& Abrao 1984) and in mangrove sediments in the Brisbane river, Australia (Mackey et al. 1992).
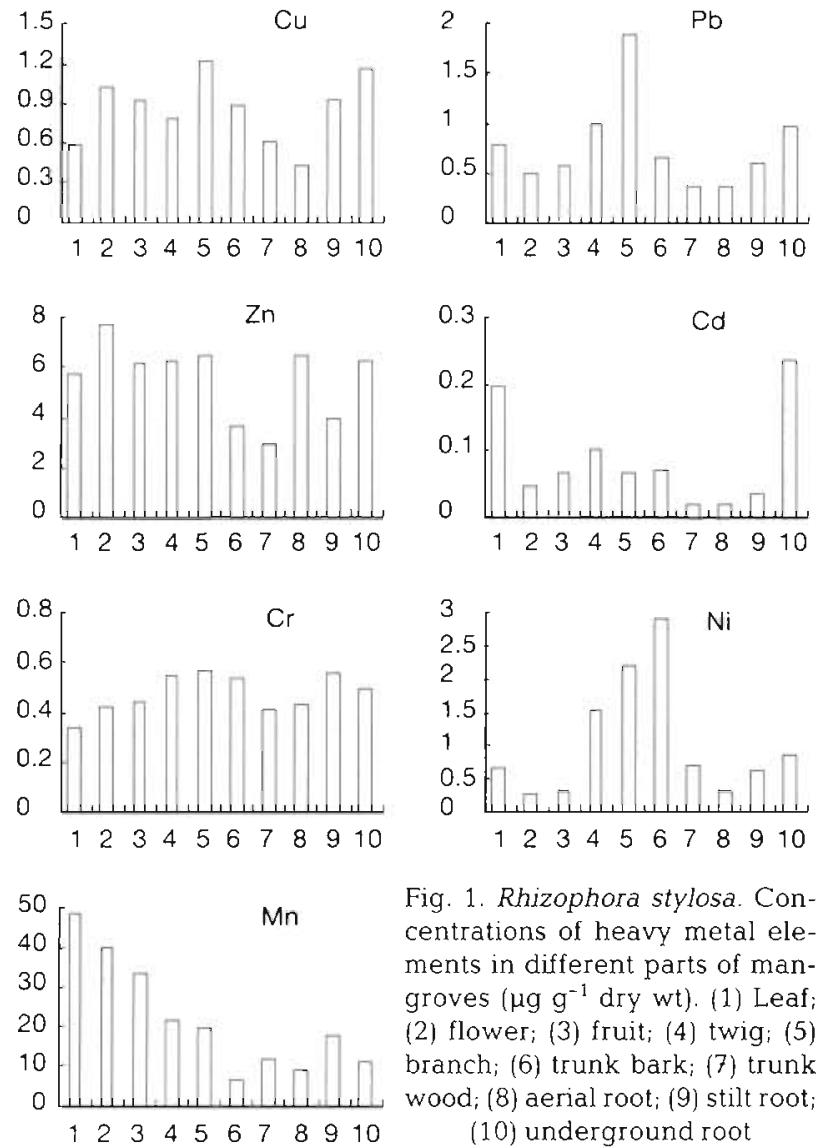

Fig. 1. Rhizophora stylosa. Concentrations of heavy metal elements in different parts of mangroves ( $\mu \mathrm{g} \mathrm{g}^{-1}$ dry wt). (1) Leaf; (2) flower; (3) fruit; (4) twig; (5) branch; (6) trunk bark; (7) trunk wood; (8) aerial root; $(9)$ stilt root;

(10) underground root

Heavy metal concentrations in different parts of Rhizophora stylosa

The concentrations of heavy metals in different parts of Rhizophora stylosa are shown in Fig. 1. Evident differences of concentrations of most heavy metals were observed in different parts of the mangroves, and weighted means were $0.98,0.86,4.91,0.11,0.50,1.06$ and $14.60 \mu \mathrm{g} \mathrm{g}^{-1}$ dry wt for $\mathrm{Cu}, \mathrm{Pb}, \mathrm{Zn}, \mathrm{Cd}, \mathrm{Cr}, \mathrm{Ni}$ and $\mathrm{Mn}$, respectively. The mean metal concentrations decreased in an order similar to that in the sediments. The highest concentrations of $\mathrm{Cu}, \mathrm{Pb}$ and $\mathrm{Cr}$ were recorded in branches, and those of $\mathrm{Zn}, \mathrm{Cd}, \mathrm{Ni}$ and $\mathrm{Mn}$ were in flowers, underground roots, trunk bark and leaves, respectively. The lowest concentrations of $\mathrm{Cu}$

Table 1. Rhizophora stylosa, Kandelia candel and Avicennia marina. Heavy metal concentrations in sediments (depth 0 to $30 \mathrm{~cm}$ ) of 3 estuary mangroves in China ( $\mu \mathrm{g} \mathrm{g}^{-1}$ dry wt)

\begin{tabular}{|c|c|c|c|c|c|c|c|}
\hline Mangroves & $\mathrm{Cu}$ & $\mathrm{Pb}$ & $\mathrm{Zn}$ & $\mathrm{Cd}$ & $\mathrm{Cr}$ & $\mathrm{Ni}$ & $\mathrm{Mn}$ \\
\hline Rhizophora stylosa, Yingluo Bay & 18.9 & 10.0 & 46.6 & 0.077 & 9.27 & 14.6 & 89.5 \\
\hline Kandelia candel, Jiulong River Estuary ${ }^{a}$ & 29.7 & 18.3 & 111.0 & 0.094 & 4.73 & 16.9 & 583.0 \\
\hline Avicennia marina, Shenzhen Bay ${ }^{b}$ & 38.3 & 28.7 & 114.0 & 0.136 & 7.97 & 25.0 & 537.0 \\
\hline
\end{tabular}



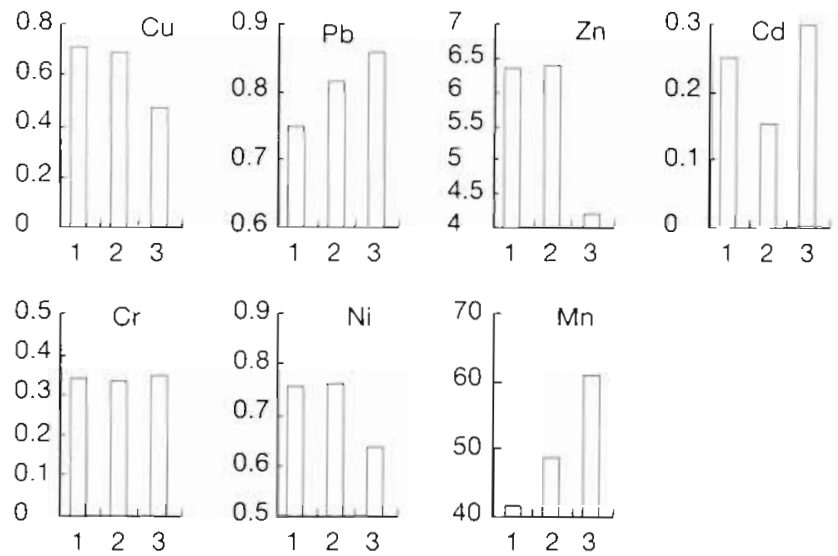

Fig. 2. Rhizophora stylosa. Changes of concentrations $\left(\mu \mathrm{g} \mathrm{g}^{-1}\right.$ dry wt) of heavy metal elements in leaves at different stages of development in mangroves. (1) Young leaf (first leaf pair); (2) mature leaf (third leaf pair); (3) yellow leaf (turning yellow for senescence)

and $\mathrm{Ni}$ were in aerial roots and flowers, and $\mathrm{Pb}, \mathrm{Zn}$ and $\mathrm{Cd}$ were lowest in trunk wood, and $\mathrm{Cr}$ and $\mathrm{Mn}$ were lowest in leaves and trunk bark, respectively.

Heavy metal concentrations in leaves at different developmental stages were also determined. Different changes in heavy metal concentration were found in leaves as they developed (Fig. 2). $\mathrm{Pb}$ and $\mathrm{Mn}$ concentrations increased gradually with leaf development. Concentrations of $\mathrm{Cu}, \mathrm{Zn}$ and $\mathrm{Ni}$ were similar in young and mature leaves, higher than those in yellow leaves. The change in $\mathrm{Cr}$ concentration was not evident.

Heavy metal concentrations in litter falls and residues on the floor

Table 2 shows the concentrations of heavy metals in different fractions of litter falls. The concentrations of $\mathrm{Cu}, \mathrm{Cr}$, $\mathrm{Pb}$ and $\mathrm{Zn}$ were highest in litter fall flowers or branches $(1.31,0.59,2.48$, $8.25 \mu \mathrm{g} \mathrm{g}^{-1}$ dry wt, respectively), and lowest in litter fall fruits and leaves $\left(0.62,0.36,0.52,5.00 \mu \mathrm{g} \mathrm{g}^{-1}\right.$ dry wt, respectively). The highest concentrations of $\mathrm{Cd}$ and $\mathrm{Mn}$ were found in litter fall leaves, and the lowest in litter fall fruits. Concentrations of heavy metals in leaf residue were much higher than those in branch residue, especially of $\mathrm{Zn}$ and $\mathrm{Pb}$. It is noteworthy that the concentrations of all the 7 heavy metals except $\mathrm{Ni}$ of each fraction in residues were higher than those in litter fall. The concentra- tions of heavy metals in leaf residue were 1.3 to 28.6 times of those in litter fall leaves, and in branch residue were 1.1 to 3.8 times of those in litter fall branches.

\section{Ability of Rhizophora stylosa to absorb heavy metals in soil}

The weighted average accumulation coefficients of Rhizophora stylosa for 7 elements in topsoil in Yingluo Bay were in the order $\mathrm{Cd}>\mathrm{Mn}>\mathrm{Zn}>\mathrm{Pb}>\mathrm{Ni}>\mathrm{Cu}=\mathrm{Cr}$ (Table 3). Most of them were lower than 0.2, but that of $\mathrm{Cd}$ was 1.395. The accumulation coefficients of $\mathrm{Cu}, \mathrm{Pb}$, $\mathrm{Zn}, \mathrm{Cr}$ and $\mathrm{Ni}$ in each fraction were lower than 0.2 , and those of $\mathrm{Mn}$ (except 0.535 for leaf) were lower than 0.5 . However, the accumulation coefficients of $\mathrm{Cd}$ in leaf, twig and underground root were 1.3 to 3.0, and those in other fractions were lower than 1 . The results showed that $R$. stylosa forest had different absorption and accumulation abilities for different heavy metals in natural habitat conditions. Among them, Cd was the easiest to be absorbed, next $\mathrm{Mn}$, and $\mathrm{Cr}$ and $\mathrm{Cu}$ were the last.

\section{Amounts and distributions of heavy metals in Rhizophora stylosa forest}

The standing amounts of $\mathrm{Cu}, \mathrm{Pb}, \mathrm{Zn}, \mathrm{Cd}, \mathrm{Cr}, \mathrm{Ni}$ and $\mathrm{Mn}$ in Rhizophora stylosa forest in Yingluo Bay were

Table 2. Rhizophora stylosa. Concentration of heavy metal elements in litter fall and residues on the floor in a mangrove community ( $\mu \mathrm{g} \mathrm{g}^{-1}$ dry $w \mathrm{t}$ )

\begin{tabular}{|lrrrrrrrr}
\hline Fraction & & $\mathrm{Cu}$ & $\mathrm{Pb}$ & $\mathrm{Zn}$ & $\mathrm{Cd}$ & $\mathrm{Cr}$ & $\mathrm{Ni}$ & $\mathrm{Mn}$ \\
\hline Litter fall & Leaf & 0.62 & 1.06 & 5.00 & 0.224 & 0.36 & 0.76 & 59.6 \\
& Flower & 1.31 & 2.48 & 6.95 & 0.050 & 0.59 & 0.54 & 34.5 \\
& Fruit & 0.69 & 0.52 & 6.29 & 0.034 & 0.44 & 0.32 & 13.3 \\
& Branch & 1.09 & 1.84 & 8.25 & 0.064 & 0.59 & 2.08 & 19.1 \\
Residue & Leaf & 15.50 & 25.00 & 143.00 & 0.476 & 1.18 & 3.32 & 77.2 \\
& Branch & 4.13 & 1.94 & 16.60 & 0.120 & 0.80 & 1.08 & 38.0 \\
\end{tabular}

Table 3. Rhizophora stylosa. Accumulation coefficient of mangroves from the soil

\begin{tabular}{|lccccccc|}
\hline Fraction & $\mathrm{Cu}$ & $\mathrm{Pb}$ & $\mathrm{Zn}$ & $\mathrm{Cd}$ & $\mathrm{Cr}$ & $\mathrm{Ni}$ & $\mathrm{Mn}$ \\
\hline Leaf & 0.031 & 0.080 & 0.121 & 2.523 & 0.036 & 0.045 & 0.535 \\
Flower & 0.053 & 0.050 & 0.164 & 0.595 & 0.045 & 0.019 & 0.442 \\
Fruit & 0.048 & 0.058 & 0.132 & 0.854 & 0.047 & 0.022 & 0.366 \\
Twig & 0.042 & 0.099 & 0.134 & 1.307 & 0.059 & 0.104 & 0.237 \\
Branch & 0.064 & 0.188 & 0.139 & 0.867 & 0.061 & 0.149 & 0.220 \\
Trunk bark & 0.046 & 0.065 & 0.078 & 0.918 & 0.057 & 0.198 & 0.073 \\
Trunk wood & 0.032 & 0.037 & 0.063 & 0.259 & 0.044 & 0.048 & 0.127 \\
Aerial root & 0.023 & 0.037 & 0.138 & 0.259 & 0.045 & 0.022 & 0.103 \\
Stilt root & 0.049 & 0.059 & 0.084 & 0.453 & 0.060 & 0.044 & 0.198 \\
Underground root & 0.060 & 0.096 & 0.134 & 3.014 & 0.053 & 0.059 & 0.123 \\
Weighted average & 0.052 & 0.086 & 0.105 & 1.395 & 0.054 & 0.072 & 0.163 \\
& & & & & & & \\
\hline
\end{tabular}


$28.73,25.25,143.68,3.14,14.61,30.87$ and $430.39 \mathrm{mg}$ $\mathrm{m}^{-2}$, respectively (Table 4 ). Cd was higher in underground than in aboveground fractions and the others were converse. Compared with other mangroves (Zheng \& Lin 1996a, b, W. J Zheng et al. 1996a, b), the amounts of $\mathrm{Cu}, \mathrm{Zn}$ and $\mathrm{Mn}$ were only $53.5,76.5$ and $26.4 \%$ of those of corresponding elements in Avicennia marina forest, and $36.3,42.8$ and $5.4 \%$ in Kandelia candel forest, respectively, whereas the amounts of $\mathrm{Cd}, \mathrm{Cr}$ and $\mathrm{Ni}$ were $4.4,2.4$ and 1.5 times those of corresponding elements in A. marina forest, and 2.7 , 4.2 and 2.9 times those in $K$. candel forest, respectively.

The residues in Rhizophora stylosa forest in Yingluo Bay were only $35.36 \mathrm{~g} \mathrm{~m}^{-2}$. The estimated potential amounts of the 7 heavy metals in the residues were $271.7,323.5,1983.8,8.2,32.4,63.0$ and $1776.9 \mu \mathrm{g} \mathrm{m}^{-2}$ for $\mathrm{Cu}, \mathrm{Pb}, \mathrm{Zn}, \mathrm{Cd}, \mathrm{Cr}, \mathrm{Ni}$ and $\mathrm{Mn}$, respectively, among which the amount in residue leaves made up 63.0,
$85.4,79.7,64.3,40.1,58.3$ and $48.0 \%$ of the total, respectively (Table 5). It showed that the amounts of the 7 heavy metals in residues were low though concentrations were high. The potential amounts of the 7 elements, except $\mathrm{Pb}$, were also lower than those in the Kandelia candel forest (W. J. Zheng et al. 1996a, b) . and those in the Avicennia marina forest (Zheng \& Lin 1996a, b).

\section{Biological cycles of heavy metals in Rhizophora stylosa forest}

The annual retention of $\mathrm{Cu}, \mathrm{Pb}, \mathrm{Zn}, \mathrm{Cd}, \mathrm{Cr}, \mathrm{Ni}$ and $\mathrm{Mn}$ in the Rhizophora stylosa forest in Yingluo Bay was $842.5,806.9,4694.2,95.0,464.9,1054.0$ and $14038.9 \mu \mathrm{g}$ $\mathrm{m}^{-2}$, respectively, which were in the order $\mathrm{Mn}>\mathrm{Zn}>$ $\mathrm{Ni}>\mathrm{Cu}>\mathrm{Pb}>\mathrm{Cr}>\mathrm{Cd}$ (Table 6$)$. The retention of $\mathrm{Cu}$,

Table 4. Rhizophora stylosa. Total amount of heavy metal elements in the mangrove community ( $\mu g \mathrm{~m}^{-2}$ )

\begin{tabular}{|c|c|c|c|c|c|c|c|c|}
\hline Fraction & Biomass $^{\mathrm{d}}\left(\mathrm{g} \mathrm{m}^{-2}\right)$ & $\mathrm{Cu}$ & $\mathrm{Pb}$ & $\mathrm{Zn}$ & $\mathrm{Cd}$ & $\mathrm{Cr}$ & $\mathrm{Ni}$ & $\operatorname{Mn}\left(\times 10^{3}\right)$ \\
\hline Leaf & 685.1 & 405.6 & 540.5 & 3877.7 & 133.6 & 226.1 & 448.1 & 32.82 \\
\hline Flower and fruit & 17.6 & 16.2 & 10.1 & 111.6 & 1.1 & 7.6 & 5.6 & 0.59 \\
\hline Twig & 198.6 & 156.5 & 196.8 & 1239.3 & 20.1 & 108.2 & 301.9 & 4.21 \\
\hline Branch & 4133.5 & 5501.5 & 7771.0 & 26826.4 & 276.9 & 2323.0 & 8969.7 & 81.43 \\
\hline Dead branch & 188.2 & 436.6 & 297.4 & 1364.5 & 14.9 & 122.0 & 265.4 & 2.80 \\
\hline Trunk bark & 1392.4 & 1208.6 & 906.5 & 5082.3 & 98.9 & 738.0 & 4024.0 & 9.13 \\
\hline Trunk wood & 5547.7 & 3339.7 & 2047.1 & 16310.2 & 111.0 & 2280.1 & 3844.6 & 63.24 \\
\hline Aerial root & 86.5 & 37.5 & 32.2 & 555.3 & 1.7 & 36.4 & 27.9 & 0.79 \\
\hline Stilt root & 7371.6 & 6759.9 & 4334.6 & 28897.5 & 258.0 & 4069.2 & 4710.6 & 130.48 \\
\hline Underground root & 9536.8 & 10872.0 & 9117.2 & 59414.3 & 2222.1 & 4701.6 & 8268.4 & 104.90 \\
\hline Total & 29158.0 & 28734.1 & 25253.4 & 143679.1 & 3138.3 & 14612.2 & 30866.2 & 430.39 \\
\hline \multicolumn{9}{|c|}{ ¿Data from Lin et al. (1992) } \\
\hline
\end{tabular}

Table 5. Rhizophora stylosa. Total amount of heavy metal elements in residues on the floor of mangroves $\left(\mu g \mathrm{~m}^{-2}\right)$

\begin{tabular}{|lcrrrrrrr|}
\hline Fraction & Residues $^{a}\left(\mathrm{~g} \mathrm{~m}^{-2}\right)$ & $\mathrm{Cu}$ & $\mathrm{Pb}$ & $\mathrm{Zn}$ & $\mathrm{Cd}$ & $\mathrm{Cr}$ & $\mathrm{Ni}$ & $\mathrm{Mn}$ \\
\hline Residue leaves & 11.05 & 171.3 & 276.3 & 1580.2 & 5.26 & 13.0 & 36.7 & 853.1 \\
Residue branches & 24.31 & 100.4 & 47.2 & 403.6 & 2.92 & 19.4 & 26.3 & 923.8 \\
Total & 35.36 & 271.7 & 323.5 & 1983.8 & 8.18 & 32.4 & 63.0 & 1776.9 \\
a Data from Lin et al. (1992) & & & & & & & & \\
\hline
\end{tabular}

Table 6. Rhizophora stylosa. Annual retentions of heavy metal elements in mangroves ( $\left.\mu \mathrm{g} \mathrm{m}^{-2} \mathrm{yr}^{-1}\right)$

\begin{tabular}{|lrrrrrrrr}
\hline Fraction & Annual increment & ( $\left(\mathrm{g} \mathrm{m}^{-2}\right)$ & $\mathrm{Cu}$ & $\mathrm{Pb}$ & $\mathrm{Zn}$ & $\mathrm{Cd}$ & $\mathrm{Cr}$ & $\mathrm{Ni}$ \\
\hline Twig & 198.65 & 156.5 & 196.9 & 1239.6 & 20.1 & 108.3 & 301.9 & \multicolumn{2}{c}{$\mathrm{Mn}$} \\
Perennial branch & 104.16 & 126.0 & 195.8 & 676.0 & 7.0 & 58.5 & 226.0 & 2052.0 \\
Trunk bark & 35.09 & 30.5 & 22.8 & 128.1 & 2.5 & 18.6 & 101.4 & 230.2 \\
Trunk wood & 139.80 & 84.2 & 51.6 & 411.0 & 2.8 & 57.5 & 96.9 & 1593.7 \\
Aboveground root & 187.94 & 171.3 & 110.0 & 742.2 & 6.6 & 103.5 & 119.4 & 3308.0 \\
Underground root & 240.33 & 274.0 & 229.8 & 497.3 & 56.0 & 118.5 & 208.4 & 2643.6 \\
Total & 905.97 & 842.5 & 806.9 & 4694.2 & 95.0 & 464.9 & 1054.0 & 14038.9 \\
a Data from Lin et al. (1992) & & & & & & & & \\
\hline
\end{tabular}


$\mathrm{Pb}, \mathrm{Zn}, \mathrm{Cd}, \mathrm{Cr}, \mathrm{Ni}$ and $\mathrm{Mn}$ in the root accounted for $48.8,42.1,26.4,65.9,47.8,31.1$ and $42.4 \%$ of the total, respectively. The annual retention of $\mathrm{Cu}, \mathrm{Pb}, \mathrm{Zn}$ and Mn was only $20.7,61.2,28.7$ and $13.0 \%$ of that of corresponding elements, respectively, by comparison with Avicennia marina mangroves (Zheng \& Lin 1996a, b) and was $10.6,22.3,15.4$ and $2.1 \%$ of corresponding elements by comparison with Kandelia candel mangroves (W. J. Zheng et al. 1996a, b).

Annual return of $\mathrm{Cu}, \mathrm{Pb}, \mathrm{Zn}, \mathrm{Cd}, \mathrm{Cr}, \mathrm{Ni}$ and $\mathrm{Mn}$ in Rhizophora stylosa mangroves was 509.2, 806.2, $4114.3,146.0,294.6,573.7$ and $39653.1 \mu \mathrm{g} \mathrm{m}{ }^{-2}$, respectively, with the order $\mathrm{Mn}>\mathrm{Zn}>\mathrm{Pb}>\mathrm{Ni}>\mathrm{Cu}>\mathrm{Cr}>\mathrm{Cd}$ (Table 7). Litter fall leaves were the main route of return, and their return amounts of $\mathrm{Cu}, \mathrm{Pb}, \mathrm{Zn}, \mathrm{Cd}, \mathrm{Cr}$, $\mathrm{Ni}$ and $\mathrm{Mn}$ were $75.8,82.0,75.8,95.8,75.8,82.8$ and $93.8 \%$ of the total, respectively.

The annual uptakes of $\mathrm{Cu}, \mathrm{Pb}, \mathrm{Zn}, \mathrm{Cd}, \mathrm{Cr}, \mathrm{Ni}$ and $\mathrm{Mn}$ in Rhizophora stylosa mangroves were 1351.7, 1613.1, $8808.4,240.7,759.5,1627.7$ and $53692.0 \mu \mathrm{g} \mathrm{m} \mathrm{m}^{-2}$ in which the retention ratios were $62.3,50.0,53.3,39.4$, $61.2,64.8$ and $26.1 \%$ of the total, and the return ratios were $37.7,50.0,46.7,60.6,38.8,35.2$ and $73.9 \%$ of the total for $\mathrm{Cu}, \mathrm{Pb}, \mathrm{Zn}, \mathrm{Cd}, \mathrm{Cr}, \mathrm{Ni}$ and $\mathrm{Mn}$, respectively. That is, retention $>$ return for $\mathrm{Cu}, \mathrm{Zn}, \mathrm{Cr}$ and $\mathrm{Ni}$; return > retention for $\mathrm{Cd}$ and $\mathrm{Mn}$; and retention = return for $\mathrm{Pb}$. Relations among annual uptakes, retentions and returns are summarized in Fig. 3.

The calculated turnover periods of $\mathrm{Cu}, \mathrm{Pb}, \mathrm{Zn}, \mathrm{Cd}$, $\mathrm{Cr}, \mathrm{Ni}$ and $\mathrm{Mn}$ of Rhizophora stylosa mangroves in Yingluo Bay were 56, 31, 35, 22, 50, 54 and $11 \mathrm{yr}$, respectively. These indicated that the speeds of turnover were in the order $\mathrm{Mn}>\mathrm{Cd}>\mathrm{Pb}>\mathrm{Zn}>\mathrm{Cr}>$ $\mathrm{Ni}>\mathrm{Cu}$ in $\mathrm{R}$. stylosa mangroves. Compared with other elements in this forest, the turnover periods of $\mathrm{Cu}, \mathrm{Pb}$, $\mathrm{Zn}, \mathrm{Cd}, \mathrm{Cr}$ and $\mathrm{Ni}$ were longer than $\mathrm{K}, \mathrm{Na}, \mathrm{Mg}, \mathrm{Cl}$, indicating that the turnover ratios of heavy metals, except $\mathrm{Mn}$, were rather low. The turnover periods of the 7 heavy metals except $\mathrm{Pb}$ in $R$. stylosa were much longer than those of corresponding elements in Kandelia candel (W J. Zheng et al. 1996a, b).

The absorption coefficient sequence of the 7 heavy metals was $\mathrm{Cd}>\mathrm{Mn}>\mathrm{Pb}=\mathrm{Zn}>\mathrm{Ni}>\mathrm{Cu}=\mathrm{Cr}$ (Table 8). The utilization coefficient sequence, however, was in

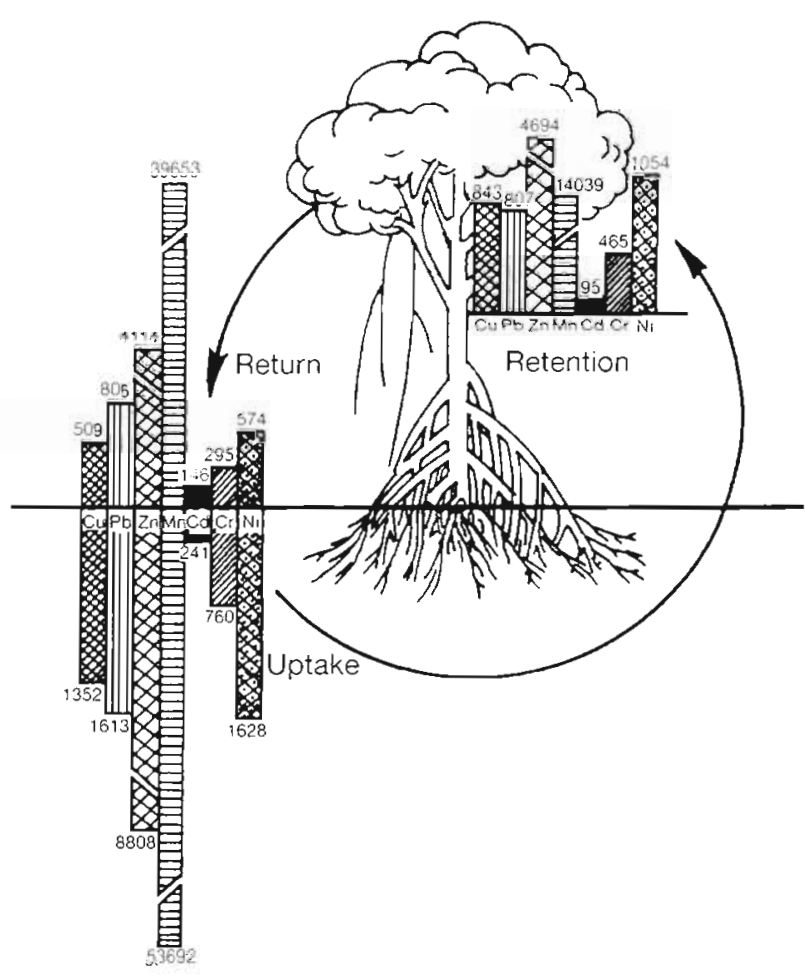

Fig. 3. Rhizophora stylosa. Biological cycling of heavy metal elements in the mangrove community $\left(\mu \mathrm{g} \mathrm{m}^{-2} \mathrm{yr}^{-1}\right.$ )

the order $\mathrm{Mn}>\mathrm{Cd}>\mathrm{Pb}=\mathrm{Zn}>\mathrm{Cr}=\mathrm{Ni}>\mathrm{Cu}$. The sequence of cycling coefficients was the same as the utilization coefficient which suggested that the flows of $\mathrm{Mn}$ and $\mathrm{Cd}$ were high, while those of $\mathrm{Cu}, \mathrm{Cr}$ and $\mathrm{Ni}$ were low, coinciding with the conclusion of the turnover analysis.

\section{DISCUSSION}

Mangrove wetlands are generally considered to be apt to trap heavy metals, because of their high organic material content and tiny sediment grain size. But the concentrations of $\mathrm{Cu}, \mathrm{Pb}, \mathrm{Zn}, \mathrm{Cd}, \mathrm{Cr}, \mathrm{Ni}$ and $\mathrm{Mn}$ of sediments (0 to $30 \mathrm{~cm}$ deep) in the Rhizophora stylosa forest of Yingluo Bay were relatively low, especially $\mathrm{Mn}$, $\mathrm{Zn}, \mathrm{Pb}$ and $\mathrm{Cd}$, compared with other mangrove estuar-

Table 7. Rhizophora stylosa. Annual return of heavy metal elements in mangrove community ( $\mu \mathrm{gm}^{-2} \mathrm{yr}^{-1}$ )

\begin{tabular}{|lrrrrrrrr}
\hline Fraction & Annual amount ${ }^{\mathrm{a}}\left(\mathrm{g} \mathrm{m}^{-2}\right)$ & $\mathrm{Cu}$ & $\mathrm{Pb}$ & $\mathrm{Zn}$ & $\mathrm{Cd}$ & $\mathrm{Cr}$ & $\mathrm{Ni}$ & $\mathrm{Mn}$ \\
\hline Fall leaves & 623.9 & 386.2 & 661.3 & 3119.5 & 139.8 & 223.4 & 474.8 & 37183.8 \\
Fall flowers & 16.2 & 21.2 & 40.2 & 112.5 & 0.8 & 9.6 & 8.8 & 558.6 \\
Fall fruits & 104.3 & 72.1 & 54.5 & 657.2 & 3.6 & 45.6 & 33.4 & 1389.7 \\
Fall. branches & 27.3 & 29.7 & 50.2 & 225.1 & 1.8 & 16.0 & 56.7 & 521.0 \\
Total & 771.9 & 509.2 & 806.2 & 4114.3 & 146.0 & 294.6 & 573.7 & 39653.1 \\
atata from F Z. Zheng et al. (1996) & & & & & & & \\
\hline
\end{tabular}


heavy metals in the mangrove ecosystem were mainly stored in the sediments, and the amounts in the mangroves were small.

With the development of leaves from young to old, the changes in concentrations of heavy metals in leaves indicated that $\mathrm{Pb}, \mathrm{Cd}$ and $\mathrm{Mn}$ were apt to be accumulated in older leaves, whereas $\mathrm{Cu}, \mathrm{Zn}$ and $\mathrm{Ni}$ were not. $\mathrm{Cu}, \mathrm{Zn}$ and $\mathrm{Mn}$ are essential elements of plants, and the decreasing of concentrations of $\mathrm{Cu}$ and $\mathrm{Zn}$ in old leaves may be because they were translocated and reused, but Mn was not. It has been reported that some essential elements were transferred and reutilized in many plant species before defoliation, while toxic materials were accumulated in older leaves and then removed via defoliation (Killingbeck 1985). The translocation efficiency of essential elements might be affected by the content level in plant and soil. High translocation happens when a plant lacks in the element, otherwise low or no translocation.

\section{CONCLUSION}

The concentrations of $\mathrm{Cu}, \mathrm{Pb}, \mathrm{Zn}, \mathrm{Cd}, \mathrm{Cr}, \mathrm{Ni}$ and $\mathrm{Mn}$ of sediments ( 0 to $30 \mathrm{~cm}$ deep) in Rhizophora stylosa forest of Yingluo Bay were 18.9, 10.0, 46.6, 0.077, 9.27, 14.6 and $89.5 \mathrm{\mu g} \mathrm{g}^{-1}$ dry wt, respectively. It is rather low compared with other mangrove zones, especially for $\mathrm{Mn}, \mathrm{Zn}, \mathrm{Pb}$ and $\mathrm{Cd}$. This suggests that the sediments of the $R$. stylosa forest were clear and less polluted by heavy metals.

Evident differences were found in the concentration of heavy metals among different parts of the plant. The weighted means were $0.98,0.86,4.91,0.11,0.50,1.06$ and $14.60 \mu \mathrm{g} \mathrm{g}^{-1}$ dry wt for $\mathrm{Cu}, \mathrm{Pb}, \mathrm{Zn}, \mathrm{Cr}, \mathrm{Cd}, \mathrm{Ni}$ and $\mathrm{Mn}$, respectively. The highest concentration of $\mathrm{Cu}$ was in branch and underground root; $\mathrm{Pb}$ in branch, $\mathrm{Zn}$ in flower, $\mathrm{Cd}$ in underground root and leaf, $\mathrm{Cr}$ in branch, bark, stilt root and twig, Ni in branch and bark, and Mn in leaf, flower and fruit.

The absorption abilities of Rhizophora stylosa for various heavy metals were different. $C d$ is the easiest to be absorbed and next was Mn. The absorption abilities for different elements decreased in the order $\mathrm{Cd}>\mathrm{Mn}>\mathrm{Zn}>\mathrm{Pb}>\mathrm{Ni}>\mathrm{Cu}=\mathrm{Cr}$ The accumulation ability of $R$. stylosa for the heavy metals, except $\mathrm{Cd}$, were very low, and the weighted means of accumulation coefficients were lower than 0.2 (Cd, 1.4). It showed that $R$. stylosa mangroves, as the primary producer, can provide clean food for the consumers.

The standing amounts of $\mathrm{Cu}, \mathrm{Pb}, \mathrm{Zn}, \mathrm{Cd}, \mathrm{Cr}, \mathrm{Ni}$ and $\mathrm{Mn}$ in Rhizophora stylosa mangroves were 28.73 , $25.25,143.68,3.14,14.61,30.87$ and $430.39 \mathrm{mg} \mathrm{m}^{-2}$, among which about 90 to $96 \%$ was stored in the parts difficult to consume by animals. It would decrease the transfer probabilities of heavy metals to secondary consumers. The residues loaded heavily with contaminant can be shifted seawards with tidal flow, alleviating the accumulation and recycling of contaminants in a mangrove zone in a way.

Different changes of heavy metal concentration were found in the leaves as they developed. $\mathrm{Pb}, \mathrm{Cd}$ and $\mathrm{Mn}$ were apt to be accumulated in older leaves, whereas $\mathrm{Cu}, \mathrm{Zn}$ and $\mathrm{Ni}$ were not. $\mathrm{Cu}$ and $\mathrm{Zn}$ are essential elements for plants, and the decreasing of concentrations of $\mathrm{Cu}$ and $\mathrm{Zn}$ indicated that they were translocated and reused.

Annual absorbed amounts of heavy metals were in the order $\mathrm{Mn}>\mathrm{Zn}>\mathrm{Ni}>\mathrm{Pb}>\mathrm{Cu}>\mathrm{Cr}>\mathrm{Cd}$, and were $53692.0, \cdot 8808.4,1627.7,1613.1,1351.7,759.5$ and $241.7 \mathrm{\mu g} \mathrm{m}^{-2} \mathrm{yr}^{-1}$ Annual retentions were 842.5, 806.9, $4694.2,95.0,464.9,1054.0$ and $14038.9 \mu \mathrm{g} \mathrm{m}^{-2} \mathrm{yr}^{-1}$ for $\mathrm{Cu}, \mathrm{Pb}, \mathrm{Zn}, \mathrm{Cd}, \mathrm{Cr}, \mathrm{Ni}$ and $\mathrm{Mn}$, respectively. Annual returns were 509.2, 806.2, 4114.3, 146.0, 294.6. 573.7 and $39653.1 \mu \mathrm{g} \mathrm{m}^{-2} \mathrm{yr}^{-1}$ for $\mathrm{Cu}, \mathrm{Pb}, \mathrm{Zn}, \mathrm{Cd}, \mathrm{Cr}, \mathrm{Ni}$ and $\mathrm{Mn}$, respectively. The turnover periods were in the order $\mathrm{Cu}>\mathrm{Ni}>\mathrm{Cr}>\mathrm{Zn}>\mathrm{Pb}>\mathrm{Cd}>\mathrm{Mn}$, and were 56, $54,50,35,31,22$ and $11 \mathrm{yr}$. All the turnover periods of heavy metals, except $\mathrm{Mn}$, were longer than some nutrient elements, i.e. $\mathrm{K}, \mathrm{Na}, \mathrm{Mg}, \mathrm{Cl}$, showing that the heavy metals usually flow more slowly than nutrient elements.

Acknowledgements. This work was supported by a China Nation Science Foundation grant to W.J.Z. The authors thank 3 anonymous reviewers for comments on a previous version of this paper and F. Z. Zheng, for providing litter fall samples.

\section{LITERATURE CITED}

Chen LZ, Lindley DK (1983) Nutrient cycling in Hampsfell bracken grassland ecosystem. England. Acta Bot Sin 25: $67-74$

Davies CA, Tomlinson K, Stephenson T (1991) Heavy metals ı.n River Tees estuary sediments. Environ Technol 12:961-972

Killingbeck KT (1985) Autumnal resorption and accretion of trace metals in gallery forest trees. Ecology 66:283-286

Lacerda LD, Abrao JJ (1984) Heavy metal accumulation by mangrove and saltmarsh intertidal sediments. Rev Bras Bot 7:49-52

Larcher W (1975) Physiological plant ecology. SpringerVerlag, Berlin

Lin P (1988) Mangrove vegetation. China Ocean Press, Beijing

Lin P, Chen RH (1989) Role of mangrove in mercury cycling and removal in Jiulong Estuary. Acta Ocean Sin 11. $242-247$

Lin P, Hu JT (1983) The mangrove communities in Guangxi. Acta Bot $\operatorname{Sin} 24: 95-97$

Lin P, Yin Y, Lu CY (1992) Biomass and productivity of Rhizophora stylosa community in Yingluo Bay of Guangxi, China. J Xiamen Uni (Nat Sci) 31:199-202

Lin P, Yin Y, Lu CY (1993) Study on the accumulation and biological cycles of $\mathrm{K}, \mathrm{Ca}$ and $\mathrm{Mg}$ in Rhizophora stylosa mangrove community in Guangxi. Acta Bot Sin 35:703-709 
Mackey AP, Hodgkinson M, Nardella R (1992) Nutrient levels and heavy metals in mangrove sediments from the Brisbane River, Australia. Mar Pollut Bull 24: 418-420

Qu ZX, Wu YS, Wang HX, Jiang HQ, Tang TG (1983) Plant ecology. The People Education Press, Beijing

Tam NFY, Li SH, Lan CY, Chen GZ, Li MS, Wong YS (1995) Nutrients and heavy metal contamination of plants and sediments in. Futian mangrove forest. Hydrobiologia 295: $149-158$

Teas HJ (1979) Silviculture with saline water In: Hollaender A (ed) The biosaline concept. Plenum Publishing Corporation, New York, p 117-161

Walsh GE, Ainsworth KA, Rigby R (1979) Resistance of red mangrove (Rhizophora mangle L.) seedlings to lead, cadmium and mercury. Biotropica 11:22-27

Zheng FZ, Lin P, Lu CY, Zheng WJ, Yin Y (1996) Litter fall production and energy flow through the litter of Rhizophora stylosa Griff. mangrove community in Yingluo Bay of Guangxi, China. J Xiamen Uni (Nat Sci) 35:417-423

Editorial responsibility: Otto Kinne (Editor),

Oldendorf/Luhe, Germany
Zheng WJ, Lin P (1992) Dynamics of $\mathrm{Cl}$ and $\mathrm{Na}$ in Rhizophora stylosa mangrove community in Guangxi. Acta bot Sin $34: 378-385$

Zheng WJ, Lin P (1996a) Accumulation and distribution of $\mathrm{Cu}, \mathrm{Pb}, \mathrm{Zn}$ and $\mathrm{Cd}$ in Avicenna marina mangrove comnmunity of Futian in Shenzhen. Oceanol Limnol Sin 27 : 386-393

Zheng WJ, Lin P (1996b) Accumulation and distribution of Cr, $\mathrm{Ni}$ and $\mathrm{Mn}$ in Avicennia marina mangrove community of Futian in Shenzhen. Chin J Appl Ecol 7:139- 144

Zheng WJ, Zheng FZ, Lian YW, Lin P (1996a) Accumulation and dynamics of $\mathrm{Cu}, \mathrm{Pb}, \mathrm{Zn}$ and $\mathrm{Mn}$ elements in Kandelia candel (L.) Druce mangrove community of Jiulong river estuary of Fujian. Acta Bot Sin 38:227-233

Zheng WJ, Zheng FZ, Lian YW, Lin P (1996b) Accumulation and dynamics of cadmium, chromium and nickel in Kandelia candel (L.) Druce mangrove community of Jiulong river estuary of Fujian. Acta Scientiae Circumstantiae 16: $232-237$

Submitted: January 23, 1997; Accepted: September 4, 1997 Proofs received from author(s): November 10, 1997 